\title{
Factors Associated with Cloth Face Covering Use Among Adults During the COVID-19 Pandemic — United States, April and May 2020
}

\begin{abstract}
Kiva A. Fisher, $\mathrm{PhD}^{1}$; John P. Barile, $\mathrm{PhD}^{2,3}$; Rebecca J. Guerin, $\mathrm{PhD}^{3}$; Kayla L. Vanden Esschert, $\mathrm{MPH}^{1}$; Alexiss Jeffers, $\mathrm{MPH}^{4,5}$; Lin H. Tian, MD ${ }^{6}$;
\end{abstract} Amanda Garcia-Williams, $\mathrm{PhD}^{1}$; Brian Gurbaxani, $\mathrm{PhD}^{1}$; William W. Thompson, $\mathrm{PhD}^{5}$; Christine E. Prue, $\mathrm{PhD}^{7}$

\begin{abstract}
On July 14, 2020, this report was posted as an MMWR Early Release on the MMWR website (https://www.cdc.gov/mmwr).

On April 3, 2020, the White House Coronavirus Task Force
\end{abstract} and CDC announced a new behavioral recommendation to help slow the spread of coronavirus disease 2019 (COVID-19) by encouraging the use of a cloth face covering when out in public (1). Widespread use of cloth face coverings has not been studied among the U.S. population, and therefore, little is known about encouraging the public to adopt this behavior. Immediately following the recommendation, an Internet survey sampled 503 adults during April 7-9 to assess their use of cloth face coverings and the behavioral and sociodemographic factors that might influence adherence to this recommendation. The same survey was administered 1 month later, during May 11-13, to another sample of 502 adults to assess changes in the prevalence estimates of use of cloth face coverings from April to May. Within days of the release of the first national recommendation for use of cloth face coverings, a majority of persons who reported leaving their home in the previous week reported using a cloth face covering (61.9\%). Prevalence of use increased to $76.4 \% 1$ month later, primarily associated with increases in use among non-Hispanic white persons $(54.3 \%$ to $75.1 \%$ ), persons aged $\geq 65$ years $(36.6 \%$ to $79.2 \%)$, and persons residing in the Midwest ( $43.7 \%$ to $73.8 \%$ ). High rates were observed in April and by May, increased further among nonHispanic black persons (74.4\% to $82.3 \%)$, Hispanic or Latino persons $(77.3 \%$ to $76.2 \%)$, non-Hispanic persons of other race $(70.8 \%$ to $77.3 \%)$, persons aged $18-29$ years $(70.1 \%$ to $74.9 \%)$ and $30-39$ years $(73.9 \%$ to $84.4 \%)$, and persons residing in the Northeast $(76.9 \%$ to $87.0 \%)$. The use of a cloth face covering was associated with theory-derived constructs that indicate a favorable attitude toward them, intention to use them, ability to use them, social support for using them, and beliefs that they offered protection for self, others, and the community. Research is needed to understand possible barriers to using cloth face coverings and ways to promote their consistent and correct use among those who have yet to adopt this behavior.

Survey questions were administered by Porter Novelli Public Services (PN) and ENGINE Insights through PN View 360,*

\footnotetext{
* Porter Novelli and ENGINE Insights collaborate on the PN View 360 surveys (http://styles.porternovelli.com/pn-view-panels). ENGINE Insights applies data quality filters that are embedded in every survey automatically and are designed to prevent cheating or speeding.
}

a rapid turnaround survey that can be used to provide insights into behaviors of the public. During April 7-9, 2020, PN administered an Internet survey via an opt-in process to a sample of 503 U.S. adults aged $\geq 18$ years using the Lucid platform (2); panel members who had not taken a survey in the previous 20 waves of survey administration were eligible to participate. The survey was administered again during May 11-13, 2020, to a separate sample of 502 adults. Quota sampling and statistical weighting were employed to make the panel representative of the U.S. population by sex, age, region, race/ethnicity, and education. Respondents were informed that their answers were being used for market research and they could refuse to answer any question at any time. No personally identifying information was included in the data file provided to CDC. ${ }^{\dagger}$ Data were obtained from 1,005 total participants, with the analysis focusing on the 839 participants who reported leaving their homes in the past week and therefore had an opportunity to wear a cloth face covering in public. Sensitivity analyses suggested that the composition of the samples of those who did and did not leave the home was comparable across points in time.

Participants were asked about their frequency of going out in public during the preceding week. Standard demographic questions were included to examine age, sex, race/ethnicity, U.S. Census region, current employment status, income level, home ownership status, and education level. Items reflecting theoretical constructs from well-established health behavior theories and models were included (3). Questions were asked to assess attitude toward the use of cloth face coverings, behavioral intention to use a cloth face covering, personal agency (i.e., ease and ability) around cloth face covering use, perceived susceptibility to infection with SARS-CoV-2 (the virus that causes COVID-19), perceived norms of cloth face covering use, and outcome expectations of wearing a cloth face covering. The survey asked about sources of information for use of cloth face coverings (e.g., health care providers, e-mail messages, and magazines). Items were measured using five-point Likert-type

\footnotetext{
CDC obtained the survey data from Porter Novelli Public Services through a subscription license. Porter Novelli Public Services and its vendors are not subject to review by CDC's Institutional Review Board; they adhere to professional standards and codes of conduct set forth by the Insights Association. https://www.insightsassociation.org/issues-policies/ insights-association-code-standards-and-ethics-market-research-and-data-analytics-0.
} 
scales ranging from 1 (never, not at all, not important, or strongly disagree) to 5 (always, completely, very important, or strongly agree) and binary scales (no or unchecked and yes or checked). Likert-type response items were dichotomized to assess agreement (strongly agree and agree versus neutral, disagree, and strongly disagree).

The outcome variable of interest was use of a cloth face covering, which was determined by the question "In the past week, when you have gone outside of your home for work, grocery shopping, or other activities that involved interacting with other people, how often did you wear a cloth face covering that covered your nose and mouth?" Cloth face covering use was defined by a response of always, often, or sometimes to this question. Participants were provided instructions that described the difference between a cloth face covering and paper disposable masks, surgical masks, dust masks, or other respirators. ${ }^{\S}$ All weighted bivariate and regression analyses were conducted using SAS software (version 9.4; SAS Institute).

Among the participants who left their home in the past 7 days, $61.9 \%$ reported using a cloth face covering in April, and this percentage increased to $76.4 \%$ in May (Table 1). Higher prevalence estimates of cloth face covering use were reported in May compared with April in all sociodemographic groups; the largest differences were reported among non-Hispanic white persons ( $54.3 \%$ to $75.1 \%$ ), persons aged $\geq 65$ years $(36.6 \%$ to $79.2 \%$ ), and persons residing in the Midwest (43.7\% to $73.8 \%$ ). High rates were observed in April and by May, increased further among black persons (74.4\% to $82.3 \%$ ), Hispanic or Latino persons (77.3\% to $76.2 \%)$, non-Hispanic persons of other race $(70.8 \%$ to $77.3 \%)$, persons aged $18-29$ years $(70.1 \%$ to $74.9 \%)$ and $30-39$ years $(73.9 \%$ to $84.4 \%)$, and persons residing in the Northeast (76.9\% to $87.0 \%)$.

Measures of well-established theoretical antecedents of behavior were associated with cloth face covering use overall (Table 2). The prevalence estimates of positive attitude toward behavior (range $=77.9 \%-81.8 \%$ ), behavioral intention $(84.2 \%-85.3 \%)$, personal agency $(78.0 \%-83.4 \%)$, perceived norms $(81.5 \%-81.9 \%)$, and outcome expectations $(74.4 \%-$ $77.4 \%)$ were associated with cloth face covering use, after adjusting for age, sex, race/ethnicity, and region, and did not change significantly from April to May. Agreement with perceived susceptibility of becoming infected with SARS-CoV-2 among those who wore a cloth face covering in the past week was $81.8 \%$. Persons who reported using cloth face coverings

\footnotetext{
\$"Most of the following questions are about the use of cloth face coverings during a viral outbreak or pandemic. Cloth face coverings, which cover a person's nose and mouth, are typically made of $100 \%$ cotton fabric and can be washed and worn over and over again. They are not the same as paper disposable masks, or surgical or N95 masks used by health care workers, or dust masks used in the construction industry."
}

received information about cloth face coverings from a variety of sources. Among those who wore cloth face coverings in the previous week, the most common sources reported were newspapers $(83.1 \%)$, health care providers $(80.8 \%)$, and the radio $(80.2 \%)$. No significant differences across information sources were found between April and May 2020.

\section{Discussion}

Days after announcing a new behavioral recommendation on April 3, adults in the United States quickly adopted the practice of using cloth face coverings, and a higher prevalence of use was reported 1 month later, in May 2020. From April to May, the prevalence of reported use of cloth face coverings was higher in all sociodemographic groups in the population, especially among non-Hispanic white persons, persons aged $\geq 65$ years, and persons residing in the Midwest, suggesting widespread acceptance of this recommendation. The increase in cloth face covering use continued to be reported as more persons began leaving their homes and going out in public more frequently from April to May. These findings are consistent with those of other organizations assessing cloth face covering use following the announcement of this recommendation $\mathbf{9}, * *, \dagger \dagger, \$ \$ \mathbf{9 5}, * * *, \dagger \dagger \dagger(4)$.

Public health authorities, including CDC, have asked persons living in the United States to engage in behaviors that are intended to reduce the risk for SARS-CoV-2 infection and slow the spread of COVID-19 (1). Use of cloth face coverings continues to be a recommendation (https://www.cdc.gov/ coronavirus/2019-ncov/prevent-getting-sick/diy-cloth-facecoverings.html) while long-term prevention measures such as vaccines are being developed. The recommendation to use cloth face coverings was based on evidence suggesting that persons with COVID-19 can transmit the SARS-Cov-2 virus to others before they develop symptoms or have an asymptomatic infection $(5,6)$. At the time of the initial recommendation, there were shortages of masks used by health care professionals and first responders (e.g., surgical masks and N95 respirators), so CDC stressed the use of cloth face coverings by the public. Over time, medical and nonmedical masks have become more available to health care workers and to the public.

\footnotetext{
https://www.ipsos.com/en-us/news-polls/abc-news-coronavirus-poll.

** https://www.rti.org/sites/default/files/covid-19_webinar-series_week_1_

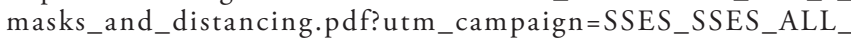
LeadGen2020\&utm_source=IntEmail\&utm_medium=Email\&utm_conte $\mathrm{nt}=$ COVID19SurveyWebinar1 PostReg.

${ }^{\dagger \dagger}$ https://www.kateto.net/COVID 19\%20CONSORTIUM\%20 REPORT\%20April\%202020.pdf.

$\$ \$$ https://www.cbsnews.com/news/americans-differ-coronavirus-impact-cbs-news-poll.

*** h t t p s : / / w w w. icf.com/ i nsights/health/ covid-19-survey-trust-government-response-erodes?utm_medium.

tit https://context-cdn.washingtonpost.com/notes/prod/default/ documents/bab35974-526c-476f-89ce-8 efe 8508 cb $49 /$ note/0b64d5b8-ad35-4ea0-a916-5dab2f070ec7.
} 
TABLE 1. Cloth face covering use among adults aged $\geq 18$ years who left the house in the past week $(N=839)$, by sex, race/ethnicity, age, region, employment status, income, home ownership, and education, by survey wave - Porter Novelli Internet survey, United States, April-May 2020

\begin{tabular}{|c|c|c|c|c|}
\hline \multirow[b]{4}{*}{ Characteristic } & \multicolumn{4}{|c|}{ Adults who left the house in past week and used cloth face covering } \\
\hline & \multicolumn{4}{|c|}{ Survey wave } \\
\hline & \multicolumn{2}{|c|}{$\begin{array}{c}\text { April 7-9, } 2020 \\
(n=408)\end{array}$} & \multicolumn{2}{|c|}{$\begin{array}{c}\text { May } 11-13,2020 \\
(n=431)\end{array}$} \\
\hline & No. & Weighted \% $(95 \% \mathrm{Cl})$ & No. & Weighted \% $(95 \% \mathrm{Cl})$ \\
\hline Total & 255 & $61.9(56.99-66.89)$ & 338 & $76.4(71.98-80.81)$ \\
\hline $\begin{array}{l}\text { Sex } \\
\text { Men } \\
\text { Women }\end{array}$ & $\begin{array}{l}129 \\
126\end{array}$ & $\begin{array}{l}61.0(54.03-68.09) \\
62.8(55.83-69.78)\end{array}$ & $\begin{array}{l}170 \\
168\end{array}$ & $\begin{array}{l}77.6(71.19-84.00) \\
75.3(69.20-81.38)\end{array}$ \\
\hline $\begin{array}{l}\text { Race/Ethnicity } \\
\text { White, non-Hispanic } \\
\text { Black, non-Hispanic } \\
\text { Hispanic or Latino } \\
\text { Other race, }{ }^{*} \text { non-Hispanic }\end{array}$ & $\begin{array}{r}154 \\
35 \\
40 \\
26\end{array}$ & $\begin{array}{l}54.3(48.11-60.41) \\
74.4(61.25-87.55) \\
77.3(65.52-89.18) \\
70.8(53.63-87.92)\end{array}$ & $\begin{array}{r}235 \\
40 \\
43 \\
20\end{array}$ & $\begin{array}{l}75.1(69.86-80.44) \\
82.3(70.68-94.01) \\
76.2(63.84-88.65) \\
77.3(59.12-95.54)\end{array}$ \\
\hline $\begin{array}{l}\text { Age group (yrs) } \\
18-29 \\
30-39 \\
40-49 \\
50-64 \\
\geq 65\end{array}$ & $\begin{array}{l}66 \\
55 \\
47 \\
63 \\
24\end{array}$ & $\begin{array}{l}70.1(60.53-79.75) \\
73.9(63.42-84.49) \\
61.4(49.47-73.31) \\
65.9(56.34-75.55) \\
36.6(24.48-48.64)\end{array}$ & $\begin{array}{l}69 \\
83 \\
53 \\
78 \\
55\end{array}$ & $\begin{array}{l}74.9(64.71-85.17) \\
84.4(76.37-92.47) \\
68.0(56.02-79.99) \\
75.3(66.60-84.06) \\
79.2(69.17-89.15)\end{array}$ \\
\hline $\begin{array}{l}\text { Census region } \\
\text { Northeast } \\
\text { Midwest } \\
\text { South } \\
\text { West }\end{array}$ & $\begin{array}{l}56 \\
34 \\
99 \\
66\end{array}$ & $\begin{array}{l}76.9(66.99-86.92) \\
43.7(32.25-55.16) \\
62.4(54.38-70.40) \\
65.2(55.37-75.01)\end{array}$ & $\begin{array}{r}66 \\
68 \\
118 \\
86\end{array}$ & $\begin{array}{l}87.0(78.28-95.81) \\
73.8(64.18-83.35) \\
71.0(63.22-78.72) \\
80.1(71.76-88.52)\end{array}$ \\
\hline $\begin{array}{l}\text { Employment status } \\
\text { Employed }^{\dagger} \\
\text { Not employed }^{\S}\end{array}$ & $\begin{array}{r}184 \\
71\end{array}$ & $\begin{array}{l}67.3(61.35-73.17) \\
52.7(44.06-61.38)\end{array}$ & $\begin{array}{l}216 \\
122\end{array}$ & $\begin{array}{l}79.5(74.16-84.80) \\
71.9(64.46-79.42)\end{array}$ \\
\hline $\begin{array}{l}\text { Income } \\
<\$ 25,000 \\
\$ 25,000-\$ 49,999 \\
\$ 50,000-\$ 99,999 \\
\geq \$ 100,000\end{array}$ & $\begin{array}{l}43 \\
69 \\
70 \\
73\end{array}$ & $\begin{array}{l}62.1(50.36-73.76) \\
60.3(50.96-69.65) \\
56.3(46.96-65.75) \\
71.3(62.24-80.27)\end{array}$ & $\begin{array}{r}55 \\
82 \\
101 \\
100\end{array}$ & $\begin{array}{l}73.1(62.71-83.42) \\
76.9(68.07-85.71) \\
72.2(64.08-80.29) \\
84.8(76.82-92.82)\end{array}$ \\
\hline $\begin{array}{l}\text { Home ownership } \\
\text { Own } \\
\text { Rent } \\
\text { Living with others at no cost }\end{array}$ & $\begin{array}{r}174 \\
67 \\
14\end{array}$ & $\begin{array}{l}66.0(59.88-72.08) \\
59.0(49.74-68.29) \\
39.6(22.33-56.91)\end{array}$ & $\begin{array}{r}202 \\
110 \\
26\end{array}$ & $\begin{array}{l}79.2(73.69-84.80) \\
78.1(70.64-85.50) \\
56.6(40.42-72.75)\end{array}$ \\
\hline $\begin{array}{l}\text { Education } \\
\text { High school or less } \\
\text { Some college to bachelor's degree } \\
\text { Any postgraduate education }\end{array}$ & $\begin{array}{r}78 \\
123 \\
54\end{array}$ & $\begin{array}{l}62.1(53.53-70.62) \\
58.8(51.82-65.86) \\
72.5(61.71-83.32)\end{array}$ & $\begin{array}{r}98 \\
180 \\
60\end{array}$ & $\begin{array}{l}71.5(63.37-79.62) \\
79.5(73.76-85.23) \\
79.1(68.84-89.33)\end{array}$ \\
\hline
\end{tabular}

Abbreviation: $\mathrm{Cl}=$ confidence interval.

* Other race includes responses of Native American/Alaska Native, Asian, and other; these were combined because of small sample size.

† Working fulltime, part time, or self-employed.

$\S$ Student, homemaker, retired, or not currently employed.

Continuing to track the sociodemographic differences and behavioral influences of use of cloth face coverings and other face masks over time is important as communities continue to monitor cases, hospitalizations, and deaths and enhance prevention strategies. Public health authorities should continue to communicate clearly the importance of cloth face covering use, especially as evidence emerges about the effectiveness of different types of face coverings and masks for offering protection from infection to self, others, and the community $(7,8)$. In addition, more research is needed among persons who do not wear cloth face coverings to understand barriers to their use.

The findings in this report are subject to at least five limitations. First, the cross-sectional opt-in survey design precludes the ability to make causal inferences about how sociodemographic and behavioral measures directly affect cloth face covering use. Internet surveys can vary in their quality and methodology (9); however, emerging research also identified similar rates of cloth face coverings in May using an independent Internet sample (4). Second, items developed for the 
TABLE 2. Attitude, behavioral intention, personal agency, perceived susceptibility, perceived norms, outcome expectations, and information sources associated with cloth face covering use among adults who left the house in the past week, by construct and information source Porter Novelli Internet survey, United States, April-May 2020

\begin{tabular}{|c|c|c|c|c|c|c|}
\hline \multirow[b]{3}{*}{ Construct and information source* } & \multicolumn{6}{|c|}{ Adults who left house in past week and used cloth face covering } \\
\hline & \multicolumn{2}{|r|}{ Total $(\mathrm{N}=593)$} & \multicolumn{2}{|c|}{ April $2020(n=255)$} & \multicolumn{2}{|c|}{ May $2020(n=338)$} \\
\hline & No. & Weighted \% $(95 \% \mathrm{Cl})$ & No. & Weighted \% (95\% Cl) & No. & Weighted \% (95\% Cl) \\
\hline \multicolumn{7}{|l|}{ Attitude toward behavior } \\
\hline $\begin{array}{l}\text { It is important for me to wear a cloth face covering } \\
\text { when I am out in public }\end{array}$ & 487 & $81.8(78.36-85.22)$ & 213 & $75.3(69.87-80.77)$ & 274 & $87.8(83.65-91.97)$ \\
\hline $\begin{array}{l}\text { It is important for everyone to wear a cloth face covering } \\
\text { when they are out in public }\end{array}$ & 493 & $79.5(76.07-82.98)$ & 213 & $71.3(65.83-76.83)$ & 280 & $87.3(83.25-91.39)$ \\
\hline $\begin{array}{l}\text { I think it is a good idea for me to wear a cloth face } \\
\text { covering while out in public }\end{array}$ & 500 & $78.1(74.61-81.66)$ & 217 & $70.7(65.26-76.13)$ & 283 & $85.2(80.81-89.68)$ \\
\hline $\begin{array}{l}\text { I think it is a good idea for everyone to wear a cloth } \\
\text { face covering while out in public }\end{array}$ & 487 & $77.9(74.31-81.42)$ & 217 & $70.7(65.24-76.10)$ & 270 & $85.1(80.70-89.61)$ \\
\hline \multicolumn{7}{|l|}{ Behavioral intention } \\
\hline $\begin{array}{l}\text { I intend to wear a cloth face covering when I } \\
\text { go to public spaces }\end{array}$ & 500 & $84.2(81.01-87.44)$ & 213 & $78.7(73.38-84.02)$ & 287 & $89.0(85.23-92.73)$ \\
\hline $\begin{array}{l}\text { I plan to wear a cloth face covering every time I } \\
\text { go out in a public space }\end{array}$ & 482 & $85.3(82.13-88.50)$ & 212 & $79.7(74.50-84.95)$ & 270 & $90.5(86.78-94.16)$ \\
\hline \multicolumn{7}{|l|}{ Personal agency } \\
\hline $\begin{array}{l}\text { Wearing a cloth face covering while I am out in public } \\
\text { is easy for me }\end{array}$ & 434 & $83.4(79.86-86.96)$ & 191 & $78.6(73.04-84.26)$ & 243 & $87.7(83.26-92.19)$ \\
\hline $\begin{array}{l}\text { I am able to wear a cloth face covering when I } \\
\text { am out in public }\end{array}$ & 510 & $78.0(74.53-81.40)$ & 216 & $70.0(64.57-75.52)$ & 294 & $85.2(81.11-89.32)$ \\
\hline \multicolumn{7}{|l|}{ Perceived susceptibility } \\
\hline $\begin{array}{l}\text { I think it is likely that I will become infected with } \\
\text { COVID-19 }\end{array}$ & 179 & $81.8(76.04-87.51)$ & 74 & $74.4(65.32-83.58)$ & 105 & $88.1(80.97-95.19)$ \\
\hline \multicolumn{7}{|l|}{ Perceived norms } \\
\hline $\begin{array}{l}\text { People who are important to me want me to wear a } \\
\text { cloth face covering when I am out in public }\end{array}$ & 468 & $81.9(78.41-85.45)$ & 201 & $76.5(70.95-82.06)$ & 267 & $86.7(82.26-91.09)$ \\
\hline $\begin{array}{l}\text { People who are important to me believe that I should } \\
\text { wear a cloth face covering when I am out in public }\end{array}$ & 474 & $81.5(78.03-84.90)$ & 196 & $74.2(68.48-79.83)$ & 278 & $87.6(83.62-91.65)$ \\
\hline \multicolumn{7}{|l|}{ Outcome expectations } \\
\hline $\begin{array}{l}\text { I would protect others from coronavirus if I wear a cloth } \\
\text { face covering when out in public }\end{array}$ & 481 & $76.8(73.19-80.48)$ & 212 & $69.5(63.95-75.13)$ & 269 & $83.9(79.33-88.51)$ \\
\hline $\begin{array}{l}\text { I would protect myself from coronavirus if I wear a cloth } \\
\text { face covering when out in public }\end{array}$ & 433 & $77.4(73.57-81.22)$ & 185 & $69.2(63.34-75.16)$ & 248 & $85.1(80.32-89.89)$ \\
\hline $\begin{array}{l}\text { Everyone wearing cloth face coverings while out in } \\
\text { public would prevent the spread of coronavirus in our } \\
\text { community }\end{array}$ & 439 & $76.3(72.48-80.11)$ & 184 & $68.1(62.16-74.05)$ & 255 & $83.8(79.05-88.54)$ \\
\hline $\begin{array}{l}\text { Wearing a cloth face covering while out in public would } \\
\text { lessen the chance that I could unknowingly spread } \\
\text { coronavirus to others }\end{array}$ & 495 & $74.4(71.82-78.02)$ & 213 & $66.3(60.81-71.74)$ & 282 & $82.4(77.81-86.96)$ \\
\hline $\begin{array}{l}\text { I can help stop the coronavirus outbreak in my } \\
\text { community if I wear a cloth face covering while } \\
\text { out in public }\end{array}$ & 469 & $76.1(72.40-79.82)$ & 201 & $68.7(63.03-74.40)$ & 268 & $83.0(78.28-87.76)$ \\
\hline \multicolumn{7}{|l|}{ Sources of information about cloth face coverings } \\
\hline TV & 395 & $72.1(68.05-76.08)$ & 173 & $64.3(58.27-70.31)$ & 222 & $79.7(74.48-84.91)$ \\
\hline Internet & 278 & $70.7(65.84-75.54)$ & 126 & $66.1(59.08-73.15)$ & 152 & 75.3 (68.69-82.01) \\
\hline Social media & 263 & $69.5(64.35-74.64)$ & 124 & $66.9(59.58-74.13)$ & 139 & $72.2(64.90-79.52)$ \\
\hline E-mail message & 134 & $78.8(71.81-85.78)$ & 71 & $77.8(68.21-87.40)$ & 63 & $80.0(69.80-90.22)$ \\
\hline Newspapers & 159 & 83.1 (77.32-88.82) & 65 & 77.3 (67.89-86.71) & 94 & $88.2(81.45-95.03)$ \\
\hline Grocery store & 188 & 77.7 (71.90-83.47) & 71 & $76.1(66.80-85.45)$ & 117 & 78.7 (71.26-86.05) \\
\hline Radio & 146 & 80.2 (73.79-86.62) & 71 & $77.1(67.75-86.45)$ & 75 & 83.3 (74.48-92.09) \\
\hline Health care provider & 187 & $80.8(75.05-86.54)$ & 65 & $80.2(70.79-89.56)$ & 122 & $81.1(73.86-88.43)$ \\
\hline
\end{tabular}

Abbreviations: $\mathrm{Cl}=$ confidence interval; COVID-19 = coronavirus disease 2019.

* Likert-type response items were dichotomized to assess agreement (strongly agree and agree versus neutral, disagree, and strongly disagree).

+ Adjusted for age, sex, race/ethnicity, and region. 


\section{Summary}

What is already known about this topic?

On April 3, 2020, the White House Coronavirus Task Force and $\mathrm{CDC}$ recommended that persons wear a cloth face covering in public to slow the spread of COVID-19.

What is added by this report?

After the initial recommendation was released, high rates of cloth face covering use were reported in the United States. An increase in the rate of cloth face covering use was observed from April to May and was sustained, particularly among non-Hispanic blacks and other races, Hispanics, persons aged $\leq 39$ years, and persons living in the Northeast.

What are the implications for public health practice?

Public health messages should target audiences not wearing cloth face coverings and reinforce positive attitudes, perceived norms, personal agency, and physical and health benefits of obtaining and wearing cloth face coverings consistently and correctly.

survey have not been used previously to assess use of cloth face coverings and require further study. Third, the use of masks that are not cloth face coverings (e.g., paper disposable masks, surgical masks, dust masks, or other respirators) was not assessed in this analysis. Fourth, the data were self-reported and might be subject to social desirability bias. Finally, this survey did not explore historical, religious, political, or cultural factors, or local mandates that might affect cloth face covering use.

These findings show higher prevalence estimates of the use of cloth face coverings in May 2020 compared with April among all sociodemographic groups. Research among persons who report not wearing a cloth face covering while in public is needed to understand potential barriers and to shape services or messages that would facilitate and encourage adoption of this recommendation. Among constructs known to influence behavior (e.g., attitude, behavioral intention, personal agency, perceived norms, and outcome expectations), there was strong agreement (>74\%) among those who wore cloth face coverings. Based on behavioral associations, messages should be targeted to reach populations not wearing cloth face coverings to promote a positive attitude toward cloth face covering use, encourage social networks to be supportive of cloth face covering use, describe positive health outcomes expected from wearing a cloth face covering, and help persons feel confident in their ability to obtain and wear cloth face coverings consistently and correctly.

\section{Acknowledgments}

John Anderton, Dogan Eroglu, Fred Fridinger, John O'Connor, CDC; Deanne Weber, Porter Novelli.

Corresponding author: Kiva A. Fisher, okm1@cdc.gov.

${ }^{1}$ CDC COVID-19 Response Team; ${ }^{2}$ Department of Psychology, University of Hawaii at Manoa; ${ }^{3}$ Division of Science Integration, National Institute for Occupational Safety and Health, CDC; ${ }^{4}$ Oak Ridge Institute for Science and Education, Oak Ridge, Tennessee; ${ }^{5}$ Division of Viral Hepatitis, National Center for HIV/AIDS, Viral Hepatitis, STD, and TB Prevention, CDC; ${ }^{6}$ Division of Human Development and Disability, National Center on Birth Defects and Developmental Disabilities, CDC; ${ }^{7}$ Office of the Director, National Center for Emerging and Zoonotic Infectious Diseases, CDC.

All authors have completed and submitted the International Committee of Medical Journal Editors form for disclosure of potential conflicts of interest. No potential conflicts of interest were disclosed.

\section{References}

1. CDC. Coronavirus disease 2019 (COVID-19). Recommendation for cloth face covers. Atlanta, GA: US Department of Health and Human Services, CDC; 2020. https://www.cdc.gov/coronavirus/2019-ncov/ prevent-getting-sick/cloth-face-cover.html

2. Coppock A, McClellan OA. Validating the demographic, political, psychological, and experimental results obtained from a new source of online survey respondents. Research \& Politics 2019;6:1-14. https://doi. org/10.1177/2053168018822174

3. Glanz K, Rimer BK, Viswanath K, eds. Health behavior and health education: theory, research, and practice. 5th ed. Philadelphia, PA: John Wiley \& Sons; 2015.

4. Czeisler MÉ, Tynan MA, Howard ME, et al. Public attitudes, behaviors and beliefs related to COVID-19, stay-at-home orders, nonessential business closures, and public health guidance-New York City, Los Angeles, and United States, May 5-12, 2020. MMWR Morb Mortal Wkly Rep 2020;69:751-8.

5. Bai Y, Yao L, Wei T, et al. Presumed asymptomatic carrier transmission of COVID-19. JAMA 2020;323:1406-7. https://doi.org/10.1001/ jama.2020.2565

6. Kimball A, Hatfield KM, Arons M, et al.; Public Health - Seattle \& King County; CDC COVID-19 Investigation Team. Asymptomatic and presymptomatic SARS-CoV-2 infections in residents of a long-term care skilled nursing facility_King County, Washington, March 2020. MMWR Morb Mortal Wkly Rep 2020;69:377-81. https://doi.org/10.15585/ mmwr.mm6913e1

7. World Health Organization. Coronavirus disease (COVID-19) advice for the public. Geneva, Switzerland; 2020. https://www.who.int/ emergencies/diseases/novel-coronavirus-2019/advice-for-public

8. Chu DK, Akl EA, Duda S, et al.; COVID-19 Systematic Urgent Review Group Effort (SURGE) study authors. Physical distancing, face masks, and eye protection to prevent person-to-person transmission of SARS-CoV-2 and COVID-19: a systematic review and meta-analysis. Lancet 2020;395:1973-87. https://doi.org/10.1016/S0140-6736(20)31142-9

9. Craig BM, Hays RD, Pickard AS, Cella D, Revicki DA, Reeve BB. Comparison of US panel vendors for online surveys. J Med Internet Res 2013;15:e260. https://doi.org/10.2196/jmir.2903 